\title{
Theoretical and Experimental Study of Nanofiltration and Reverse Osmosis Membranes for Removal of Heavy Metals from Wastewater
}

\author{
Ahmed Faiq Al-Alawy, Miqat Hasan Salih \\ Chemical Engineering Department, College of Engineering, University of Baghdad, Iraq
}

\begin{abstract}
The present work aimed to study the efficiency of nanofiltration (NF) and reverse osmosis (RO) membrane for heavy metal removal from wastewater and study the factors affecting the performance of these two membranes: feed concentrations for heavy metal ions, pressure, and flow rate. The experimental results showed, heavy metals concentration in permeate increase with raise in feed concentrations, decline with increase in flow rate. The raise of pressure, heavy metals concentration decreases for $R O$ membrane, but for $N F$ membrane the concentration decrease and then at high pressure increase. The rejection percentage for chromium in $N F$ and $R O$ is $99.7 \%$ and $99.9 \%$, for copper is $98.4 \%$ and $99.3 \%$, for zinc is $97.9 \%$ and $99.5 \%$, for nickel is $97.2 \%$ and $99.5 \%$ respectively. For a synthetic electroplating wastewater, the maximum recovery was $70.7 \%$ and $48.9 \%$ for $\mathrm{NF}$ and $\mathrm{RO}$ respectively.In general, polyamide nanofiltration and reverse osmosis membranes give a high efficiency for removal of chromium, copper, nickel and zinc. A mathematical model describing the process with the existence of the effect of concentration polarization was studied. The agreement between theoretical and experimental results has an accuracy ranging from $86-99.4 \%$ for $\mathrm{NF}$ and 93-99.9\% for RO.
\end{abstract}

Keywords:Nanofiltration, Reverse osmosis, Heavy metals, Electroplating wastewater, Mathematical model.

\section{Introduction}

As the world's population and the consequent demand for water supply increase, the world is facing a fresh water crisis around the world due to the rapid depletion of the resources of fresh water. Precious resource conservation and the sustainable development of water will require maximal recycling and reuse [1].

Heavy metals are elements having atomic weights between 63.5 and 200.6, and a specific gravity greater than 5.0 [2]. Unlike organic contaminants, heavy metals are not biodegradable, they enter the food chain and tend to accumulate in living organisms and many heavy metal ions are known to be toxic or carcinogenic. Thus, the removal of heavy metals from discharge water becomes an increasingly important issue globally. Toxic heavy metals of particular concern in treatment of industrial wastewaters include chromium, cadmium, lead, copper, mercury, nickel and zinc [3-5].

Heavy metals are very important that are used in several manufactures such as in electroplating industry, paint pigments, sugar mills, leather processing industries, paper mill, mining, plumbing, fuel additives, use in pesticides manufacturing industries, pharmaceutical industries, and PVC plastics. Which all these industries effluent have great amount of heavy metals that have to be treated before being discharged to the environment [6].

The maximum contaminant level (standards) of zinc metal in water is $<10 \mathrm{mg} / \mathrm{l}$ [7], copper metal is $4 \mathrm{mg} / \mathrm{l}$, nickel metal is $4 \mathrm{mg} / \mathrm{l}$ and chromium metal is $2 \mathrm{mg} / \mathrm{l}[8,9]$.

The electroplating industrywastewater that polluting with heavy metalsattracted increasing interest due to the development of this industry in last years. The wastewater from electroplating consist of heavy metals such as cadmium, chromium, nickel, zinc and copper, [9, 10].
Thus, various technologies have been applied for the removal of heavy metals from wastewater, such as chemical precipitation, adsorption, coagulation-flocculation, floatation, ion exchange, electrochemical processes, and membrane filtration have been developed in the recent years for decreasing the amount of wastewater produced and to improve the quality of treated water [8].

Membrane filtration may be of various types depending on the size of materials rejected by the membrane. Membrane filtration has been used successfully for the removal of heavy metals, organic substances, suspended and inorganic contaminants. Membrane filtration requires high pressure to cause water to move across the membrane form high concentration to low concentration of solute [11]. Membrane technology when compared with the traditional processes, its offer more economical benefits. The advantages of the membrane processes are: (1) Reliability. (2) Physical separation. (3) Energy consumption is low. (4) The operation is simple. (5) The maintenance and capital cost is low. (6) Versatility and flexibility. Membrane process can be operated in associated with the traditional processes [12].

The membrane systems used for heavy metals removal from wastewater is pressure driven membrane systems such as reverse osmosis (RO), nanofiltration (NF), and membrane hybrid processes [13].

$\mathrm{NF}$ membranes have been defined as a system between ultrafiltration and reverse osmosis. Nanofiltration membranes can effectively remove multivalent anions such as phosphate and sulfate because they are negatively charged. Nanofiltration membrane materials include polyamides, polyethersulfone and cellulose derivatives. The monovalent ions retention such as sodium, chloride, and etc. ranging from 20 to $80 \%$ relying on the material, manufacture of the membranes and feed concentration. Nanofiltration also rejects dissolved uncharged compounds that having a molecular weight cut off of 200 - 1000 Dalton. 


\section{International Journal of Science and Research (IJSR) \\ ISSN (Online): 2319-7064}

Index Copernicus Value (2016): 79.57 | Impact Factor (2015): 6.391

Nanofiltration membrane reduces the operating cost significantly, because the operating pressure for nanofiltration is considerably lower than that for reverse osmosis [14].

Reverse osmosis process is utilized in large plants of water treatment. RO produces a potable water of good quality from heavy metal wastewater, oily wastewater, organic wastewater, brackish water and seawater resources, reclaim polluted sources of water and decrease water salinity for industrial applications [15]. The reverse osmosis process which uses polymeric membranes to achieve selective mass transport has become the simplest and most efficient technique to desalt the seawater and brackish water. The desalination performance of a RO membrane depends largely on the membrane material and the membrane structure. An industrially useful RO membrane must exhibit several characteristics such as mechanical stability, tolerance to temperature variation, low cost, high water flux, resistance to fouling, and high salt rejection [16].

In this research, the effect of feed concentration, pressure and flow rate on flux and permeate concentration have been studied for polyamide spiral wound NF and RO membranes to remove heavy metals from electroplating wastewater.

\section{Mathematical Modeling}

In the spiral wound element water passes through the membrane element; portion of this water passes in the product stream, resulting in continuous change conditions over the length of the membrane element [17]. The model is based on the solution diffusion model is the widely used.The transport of solute and solvent are independent of each other in the solution diffusion model. The flux of solvent, which is generally water through the membrane is linearly proportional to the pressure difference and osmotic pressure difference across the membrane [18-20]:

$$
J_{w}=k_{w}(\Delta P-\Delta \pi)
$$

Where $J_{w}$ is the flux of water $\left(1 / \mathrm{m}^{2} . \mathrm{h}\right), k_{w}$ is the permeability coefficient of pure water $\left(1 / \mathrm{m}^{2}\right.$.h.bar), $\Delta P$ is theapplied pressure (bar) and $\Delta \pi$ is the osmotic pressure of the solution (bar).Solution osmotic pressure is related to its dissolved solute concentration and is predicted from Van't Hoff equation as [21]:

$$
\pi=\varphi i R_{g} T \mathrm{C}
$$

Where $\varphi$ is the osmotic coefficient, $i$ is the number of dissociated ions per molecule (Van't Hoff factor), $\mathrm{T}$ is the temperature $(\mathrm{K}), \quad \mathrm{R}_{\mathrm{g}}$ is the universal gas constant (l.bar/mole.K) and $\mathrm{C}$ is the solute concentration $(\mathrm{mg} / \mathrm{l})$. The solute flux through the membrane is proportional to the solute concentration difference across the membrane [18]:

$$
J_{s}=k_{s} \Delta C
$$

Where $J_{S}$ is the solute mass flux $\left(\mathrm{mg} / \mathrm{m}^{2} . \mathrm{h}\right), k_{s}$ is the permeability coefficient of salt $(\mathrm{m} / \mathrm{h})$ and $\Delta C$ is the concentration gradient across membrane (ppm). And:

$$
C_{P}=\frac{J_{S}}{J_{W}}
$$

Where $C_{P}$ is the concentration in permeate $(\mathrm{mg} / \mathrm{l})$.
By measuring the concentrations of solute in the feed solution $\left(C_{F}\right)$ and also in the permeate solution $\left(C_{P}\right)$, the rejection is calculated as follows [13]:

$$
R \%=\left(1-\frac{C_{P}}{C_{F}}\right) * 100 \%
$$

Where $R \%$ is the rejection percentage of solute and $C_{F}$ is the concentration in feed solution.

At steady state, the flux of solute to the membrane surface can be balanced by solute fluxes flowing away from the membrane and through the membrane as following [17]:

$$
\frac{d M}{d t}=0=J_{w} C a-D_{L} \frac{d C}{d z} a-J_{w} C_{P} a
$$

Where $M$ is the solute mass $(\mathrm{mg}), t$ is the time (s), $D_{L}$ is the solute diffusion coefficient in water $\left(\mathrm{m}^{2} / \mathrm{s}\right), z$ is the distance perpendicular to the surface of membrane $(\mathrm{m})$ and $a$ is the surface area of membrane $\left(\mathrm{m}^{2}\right)$.

Equation 6 can be not only applied at the surface of membrane but also at any plane in the boundary layer because the net flux of solute must be constant everywhere in the boundary layer to prevent the solute accumulation in that layer. By the integral of Equation 6 across the boundary layer thickness with the boundary conditions: $\mathrm{C}(0)=C_{\mathrm{M}}$ and $C\left(\delta_{B}\right)=C_{F C}$, where $C_{F C}$ is the feed concentrate channel concentration and $C_{M}$ is the membrane surface concentration.

$$
D_{L} \int_{C_{M}}^{C_{F C}} \frac{d C}{C-C_{P}}=-J_{w} \int_{0}^{\delta_{B}} d z
$$

Integrate Equation 7 as:

$$
\begin{gathered}
\ln \left(\frac{C_{M}-C_{P}}{C_{F C}-C_{P}}\right)=\frac{J_{w} \delta_{B}}{D_{L}} \\
\frac{C_{M}-C_{P}}{C_{F C}-C_{P}}=e^{\frac{J_{w} \delta_{B}}{D_{L}}}=e^{J_{w} / k_{C p}}
\end{gathered}
$$

The term used to define the accumulation of retained solute at the membrane surface so that the concentration of solute at the wall of the membrane is larger than that of the bulk feed solution is concentration polarization. The solute convective flow to the surface of membrane is much greater than the diffusion of the solute back to the bulk feed solution as the water passes through the membrane, as a result; the solute concentration at the membrane wall increases [22]. Concentration polarization is defined as the ratio of the solute concentrations of membrane and feed concentrate stream as [17]:

$$
\beta=\frac{C_{M}}{C_{F C}}
$$

Where $\beta$ is the concentration polarization factor.

Combining Equation 10 with Equations 5 and 9 gives the following expression:

$$
\beta=(1-R)+R\left(e^{J_{w} / k_{C p}}\right)
$$

In the spacer filled feed channel of a spiral wound membrane element, Schock and Miquel, 1987[23] found that the mass

\section{Volume 6 Issue 12, December 2017}




\section{International Journal of Science and Research (IJSR) \\ ISSN (Online): 2319-7064}

Index Copernicus Value (2016): 79.57 | Impact Factor (2015): 6.391

transfercoefficient of concentration polarization could be calculated from equations below, when the calculationsfor the velocity in the channel and the hydraulic diameter took the presenceof the spacer into account:

$$
\begin{gathered}
k_{C p}=0.023 \frac{D_{L}}{d_{H}}(R e)^{0.875}(S c)^{0.25} \\
R e=\frac{\rho v d_{H}}{\mu} \\
S C=\frac{\mu}{\rho D_{L}}
\end{gathered}
$$

Where $k_{C p}=D_{L} / \delta_{B}$ is the mass transfer coefficient of concentration polarization $(\mathrm{m} / \mathrm{h}), d_{H}$ is the hydraulic diameter (m), Re is the Reynold number, Sc is the Schmidt number, $v$ is the velocity in the feed stream $(\mathrm{m} / \mathrm{h}), \rho$ is the density of feed water $\left(\mathrm{kg} / \mathrm{m}^{3}\right)$ and $\mu$ is the dynamic viscosity of feed water $(\mathrm{kg} / \mathrm{m} . \mathrm{s})$.

The water and solute fluxes are expressed by Equations 1 and 3 , but the difference in concentration, difference in osmotic pressure and difference in applied pressure rely on the position in the pressure vessel [17]:

$$
\begin{array}{r}
J_{w, Z}=k_{w}\left(\Delta P_{z}-\Delta \pi_{z}\right)=k_{w}\left[\left(P_{F C, Z}-P_{P, Z}\right)-\right. \\
\pi M, Z-\pi P, Z(15) \\
J_{S, Z}=k_{S}\left(\Delta C_{z}\right)=k_{S}\left(C_{M, Z}-C_{P, Z}\right)
\end{array}
$$

Where $C_{M, Z}$ is the concentration at the surface of membrane, $C_{M, Z}=\beta_{Z} C_{F C, Z}$ and $\pi_{M, Z}$ is the osmotic pressure at the surface of membrane.

The flow of permeate and flow of mass of solute through the membrane are equal to the flux multiply by the area of membrane for the differential element. The accumulative water and solute transfer across the membrane ispredicted by integrating the flow between the feed end and the position $z$ in the pressure vessel, as:

$$
\begin{gathered}
Q_{P, z}=\int_{0}^{z} J_{w, z} w d z \\
M_{s, z}=\int_{0}^{z} J_{s, z} w d z
\end{gathered}
$$

Where $w$ is the width of feed concentrate channel (m) and $M_{s, z}$ is the solute mass transferred (mg/s). At any point in the channel the flow rate can be predicted by [17]:

$$
Q_{F C, z}=Q_{F}-Q_{P, z}
$$

The concentration of solute could be calculated as:

$$
C_{F C, z}=\frac{Q_{F} C_{F}-M_{S, Z}}{Q_{F C, z}}
$$

The flux of water and solute are influenced by solute concentration at the membrane surface and concentration polarization. Both velocity and flux are changing, $\beta$ must be determined by Equation 11:

$$
\beta_{z}=R\left(e^{\frac{J_{w, z}}{k_{C P, z}}}\right)+(1-\mathrm{R})
$$

The velocity which mass transfer coefficient $k_{C p}$ depends on it can be calculated from the following equation:

$$
\mathrm{v}_{z}=\frac{Q_{F C, z}}{h w}
$$

Where $h$ is the height of feed concentrate channel (m). The concentration of solute at the surface of membrane as a function of position expressed as:

$$
C_{M, z}=\beta_{z} C_{F C, z}
$$

The feed channel pressure drops because of the head loss, head loss changes across the length of the membrane. Turbulentconditions are maintained, so head loss in the channel is given by the expression:

$$
h_{L}=\delta_{H L} \mathrm{v}^{2} L
$$

Where $h_{L}$ is the feed concentrate channel head loss (bar), $\delta_{H L}$ is the head loss coefficient (bar.s $/ \mathrm{m}^{3}$ ), vis the velocity ofwater in feed concentrate channel $(\mathrm{m} / \mathrm{s})$ and $L$ is the length of the channel (m)

The concentration of product can be determined from the ratio of the fluxes of solute and water per Equation 4 as:

$$
C_{P, z}=\frac{J_{s, z}}{J_{w, z}}
$$

Membrane module unit in continuous operation consists of a tank for feed, a tank for product and the membrane element. The concentrate is recycled to the tank of feed so the properties of solution in feed tank changed with time and the permeate is separately collected in the product tank [24].

Recovery can be expressed as the volume of permeate divided by the initial volume of feed. This expression applied in batch concentrating mode. For the overall system, the expression is [25]:

$$
Y \%=\frac{V_{P}}{V_{F}^{o}} * 100 \%
$$

Where $Y \%$ is the recovery percentage, $V_{P}$ is the volume of permeate (1) and $V_{F}^{o}$ is the initial feed volume (l).

Material balance equation applied for the product tank as [25]:

$$
Q_{P} C_{P}=\frac{d\left(V_{P} C_{P a v g}\right)}{d t}
$$

$C_{\text {Pavg }}$ is the product average concentration $(\mathrm{mg} / \mathrm{l})$

Expansion of equation 27 yields:

$$
Q_{P} C_{P}=V_{P} \frac{d C_{P a v g}}{d t}+C_{P a v g} \frac{d V_{P}}{d t}
$$

Initial conditions, at $\mathrm{t}=0, V_{P}=0, C_{\text {Pavg }}=C_{P}=0$. The variation in the product volume corresponds to the production rate of membrane as:

$$
\frac{d V_{P}}{d t}=Q_{P}
$$




\section{International Journal of Science and Research (IJSR) \\ ISSN (Online): 2319-7064}

Index Copernicus Value (2016): 79.57 | Impact Factor (2015): 6.391

Substitution to Equation 28:

$$
\frac{d C_{\text {Pavg }}}{d t}=\frac{Q_{P}\left(C_{P}-C_{\text {Pavg }}\right)}{V_{P}}
$$

Material balance on the membrane element gives:

$$
Q_{F} C_{F}=Q_{P} C_{P}+Q_{C} C_{C}
$$

Analogous material balance equation can be obtained around the feed tank:

$$
Q_{C} C_{C}-Q_{F} C_{F}=\frac{d\left(V_{F t} C_{F t}\right)}{d t}
$$

Developing this equation gives:

$$
-Q_{P} C_{P}=V_{F t} \frac{d C_{F t}}{d t}+C_{F t} \frac{d V_{F t}}{d t}
$$

Where $V_{F t}$ is the volume in the tank of feed at a time $\mathrm{t}$, with a concentration in the $\operatorname{tank} C_{F t}$. The tank of feed is assumed well mixed [25] so:

$$
V_{F t}=V_{F}
$$

And:

$$
C_{F t}=C_{F}
$$

The variation in the feed tank volume with time corresponds to the production rate as:

$$
-\frac{d V_{F}}{d t}=Q_{P}
$$

Integrating equation 4.36 with the initial condition: $\mathrm{t}=0$, $V_{F}=V_{F}^{o}$

$$
V_{F}=V_{F}^{o}-Q_{P} t
$$

Substituting these expressions in Equation 33:

$$
\frac{d C_{F}}{d t}=\frac{Q_{P}\left(C_{F}-C_{P}\right)}{\left(V_{F}^{o}-Q_{P} t\right)}
$$

Knowing that the system of interest is closed, the conservation of mass reveals that the solute mass in feed tank at initial time is equal to the sum of various streams and tank:

$$
V_{P}=\frac{V_{F}^{o}\left(C_{F}-C_{F}^{o}\right)}{\left(C_{F}-C_{\text {Pavg }}\right)}
$$

Substituting $V_{P}$ by its expresssion in Equation 30:

$$
\frac{d C_{\text {Pavg }}}{d t}=\frac{Q_{P}\left(C_{P}-C_{\text {Pavg }}\right)}{V_{F}^{o}\left(C_{F}-C_{F}^{o}\right)}\left(C_{F}-C_{\text {Pavg }}\right)
$$

Equation 38 and 40 are the outcome of material balances on the product tank, feed tank, and membrane element. The solution of this set of ordinary differential equations requires the values of $C_{P}$ and $Q_{P} . C_{P}$ and $Q_{P}$ are obtained from the steady state equations 4 and 17 as initial values for the ordinary differential equations when the concentration and product rate of permeate change with position of module.
The solution of Equation 38 gives the concentration of feed as function of time. The solution of Equation 40 gives the solute average concentration in product tank and the volume of water by Equation 39. The equations of the mathematical model can be solved by using MATLAB PROGRAM.

\section{Materials and Methods}

Four types of feed solutions were used for the membrane process zinc chloride $\left(\mathrm{ZnCl}_{2}\right.$, Minimum assay: $\left.97.0 \%\right)$, copper chloride dihydrate $\left(\mathrm{CuCl}_{2} .2 \mathrm{H}_{2} \mathrm{O}\right.$, Minimum assay: $99.0 \%)$, nickel chloride hexahydrate $\left(\mathrm{NiCl}_{2} \cdot 6 \mathrm{H}_{2} \mathrm{O}\right.$, Minimum assay: $98.0 \%)$ and chromic chloride $\left(\mathrm{CrCl}_{3} \cdot 6 \mathrm{H}_{2} \mathrm{O}\right.$, Minimum assay: $97.0 \%$ ). Synthetic wastewater containing the desired concentrations of $\mathrm{Zn}^{+2}, \mathrm{Cu}^{+2}, \mathrm{Ni}^{+2}$ and $\mathrm{Cr}^{+3}$ were prepared by dissolving the desired amount of salts in deionized water of 1-2 $\mu \mathrm{s} / \mathrm{cm}$ conductivity. The total feed solution volume was 8 liter. The polyamide nanofiltration (AXEON NF4-1812, Active membrane area: $0.36 \mathrm{~m}^{2}$ ) and reverse osmosis (VONTRON-ULP 1812-50, Active membrane area: $0.36 \mathrm{~m}^{2}$ ) membranes were used in this work as spiral wound element. Schematic diagrams of lab-scale NF and RO system used in these experiments are shown in Fig. (1).

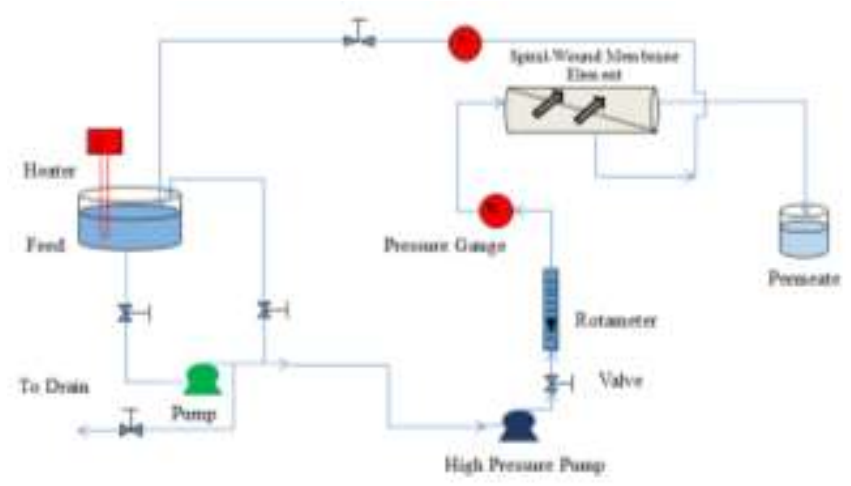

Figure 1: Schematic diagram of lab-scale RO system

Feed solution was prepared by dissolving the heavy metal compounds in 8 liter of deionized water. The feed solution drawn from the feed vessel by centrifugal pump (Model: 15 GR-18, Rated speed: 2860 r/min, Rated head: 10 m, Rated capacity: $10 \mathrm{l} / \mathrm{min}$ ) then the solution is introduced into the spiral-wound element by means of a high pressure pump (Model: HF-6050, Max. outlet pressure: 125 psi, Open flow: $1.2 \mathrm{l} / \mathrm{min})$. Pressure gauge (0-10 bar) was used in the feed line to indicate the operating pressure. The feed temperature was varied by submersible electrical coil. The feed flow rate was controlled by rotameter (Range: 10-100 1/h). The concentrate stream is recycled to the feed vessel. The water flux was obtained by dividing the permeate volume by the product of effective area of membrane and time. The concentration of heavy metal ions was measured by an atomic absorption spectrometry (Buck 210/211, Weight: 50 lbs, U.S.A., Perkin Elmer, Sr.Nr:1159 A). After each replacement for inorganic component, the membrane must be clean. For the cleaning of metallic scales low solution $\mathrm{pH}$ is used.

\section{Volume 6 Issue 12, December 2017}




\section{International Journal of Science and Research (IJSR) \\ ISSN (Online): 2319-7064}

Index Copernicus Value (2016): 79.57 | Impact Factor (2015): 6.391

\section{Results and Discussion}

The $\mathrm{pH}$ value for zinc and nickel solution is equal to $6, \mathrm{pH}$ for copper solution is equal to $5, \mathrm{pH}$ for chromium solution is equal to 4 without any adjustment of acid or base.

\subsection{Nanofiltration Process}

\subsubsection{Effect of Feed Concentration}

Figs.(2) and (3) show the effect of feed concentration on flux and the concentration of heavy metal ions in permeate respectively. The permeate flux has been decreased with increasing feed concentration. This behavior due to increase in osmotic pressure, decrease of the effective pore size of the membrane due to adsorption of solute on the surface of the membrane and the effect of concentration polarization. This behavior is agreement withAl-Rashdiet al., 2013[26]. In the case of concentrated solution flowing through the membrane the possibility of fouling inside the membrane pores would be greater, this fouling could be blocking a number of pores partly or completely, so the flux would be decreased.The increase in feed concentration of ions from 10 to $300 \mathrm{mg} / \mathrm{l}$ resulted in the decline in flux of $24.7 \%$ for zinc, $24.04 \%$ for copper, $21.43 \%$ for nickel and $26.54 \%$ for chromium.

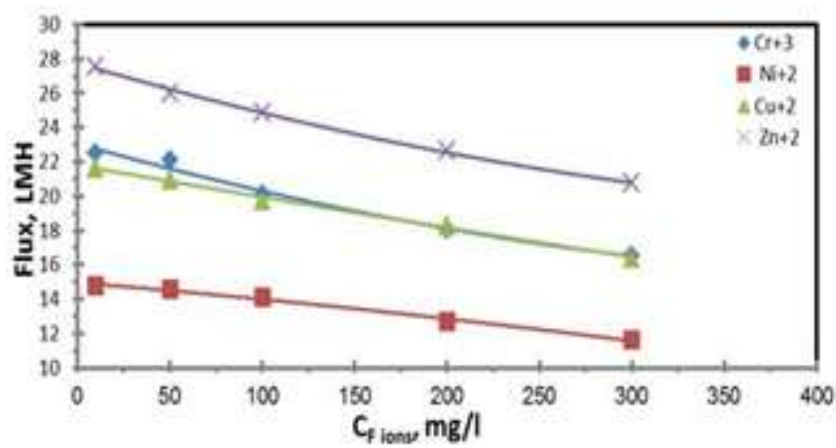

Figure 2: Effect of Feed Concentration on Flux $\left(Q_{F}=401 / h\right.$,

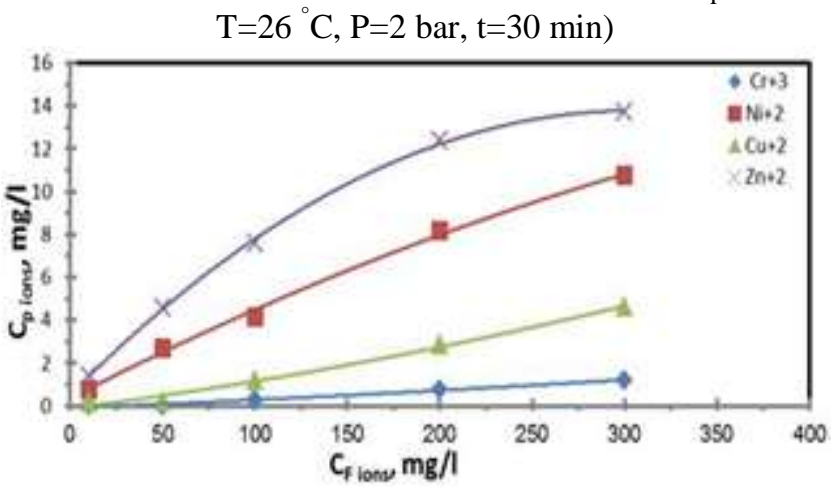

Figure 3: Effect of Feed Concentration on Permeate Concentration $\left(Q_{F}=40 \mathrm{l} / \mathrm{h}, \mathrm{T}=26^{\circ} \mathrm{C}, \mathrm{P}=2 \mathrm{bar}, \mathrm{t}=30 \mathrm{~min}\right)$

Ions concentration in permeate has been increased as the feed concentration increased, this behavior is agreement withAhn et al., 1999 [27]. The increase in feed concentration ion from 10 to $300 \mathrm{mg} / \mathrm{l}$ resulted in the increase of permeate concentration from 1.41 to $13.71 \mathrm{mg} / \mathrm{l}$ for zinc, 0.15 to 4.63 $\mathrm{mg} / \mathrm{l}$ for copper, 0.78 to $10.75 \mathrm{mg} / \mathrm{l}$ for nickel and 0 to 1.2 $\mathrm{mg} / \mathrm{l}$ for chromium. Most of the results are within the permissible limits of heavy metals in permeate.

\subsubsection{Effect of Operating Pressure}

The permeate flux has been increased with increasing applied pressure (see Fig.(4)), this behavior due to an increase of the preferential sorption of water at higher pressure, and thus the solvent permeability increases at high pressure compared with the solute permeability. The increase in applied pressure from 1 to 4 bar resulted in the increase in flux of 3.04 times for zinc, 3.18 times for copper, 3.46 times for nickel and 3.41 times for chromium. This behavior is agreement withLee et al., 2006[28].

Fig.(5) shows the effect of pressure on permeate concentration. The concentration of ions in permeate has been decreased with increasing applied pressure which can be explained by the following: The decrease in concentration of ion in permeate with raise in pressure could be because of at higher pressure the preferential sorption of the membrane element for pure water has been increased and the average pore size on the membrane surface has been decreased, also due to increase in flux with increasing applied pressure. In other words, at low pressure the solute diffusive transport through the membrane is higher than that of convective transport. As the applied pressure increases, the decrease of the concentration of ion in permeate becomes possible due to convective transport becomes more important at high pressure. This behavior was observed for nickel ions. This behavior is agreement withChai et al., 1997[29].

The increase in pressure from 1 to 4 bar resulted in the decrease of permeate concentration of nickel ions of $41.25 \%$. For zinc, chromium and copper ions the permeate concentration has been decreased where pressure increased from 1 to 2 bar and then increased at pressure from 3 to 4 bar, this behavior can be explained as the pressure increase the flux has been increased so that the level in the feed tank decreased and the feed becomes more concentrated and the concentration polarization has been increased with increasing pressure so cause an increase in permeate concentration, in this case the effect of both concentration polarization and convective transport play an important role, this behavior is agreement withAl-Rashdiet al., 2013[26].

For chromium ions the permeate concentration has been decreased $0.3 \mathrm{mg} / \mathrm{l}$ when the pressure increased from 1 to 2 bar and then increased $0.4 \mathrm{mg} / \mathrm{l}$ when the pressure increased from 3 to 4 bar. The permeate concentration has been decreased $9.84 \mathrm{mg} / \mathrm{l}$ and $0.71 \mathrm{mg} / \mathrm{l}$ when the pressure increased from 1 to 3 bar and then increased $0.44 \mathrm{mg} / \mathrm{l}$ and $3.24 \mathrm{mg} / \mathrm{l}$ when the pressure increased to 4 bar for zinc and copper ions respectively.

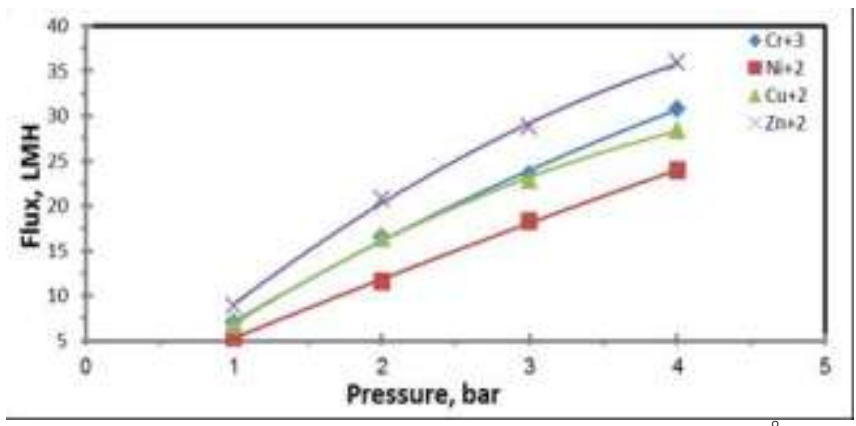

Figure 4: Effect of Pressure on Flux $\left(Q_{F}=401 / h, T=26^{\circ} \mathrm{C}, C_{F}\right.$ ions $=300 \mathrm{mg} / \mathrm{l}, \mathrm{t}=30 \mathrm{~min}$ )

Volume 6 Issue 12, December 2017 www.ijsr.net 
International Journal of Science and Research (IJSR)

ISSN (Online): 2319-7064

Index Copernicus Value (2016): 79.57 | Impact Factor (2015): 6.391

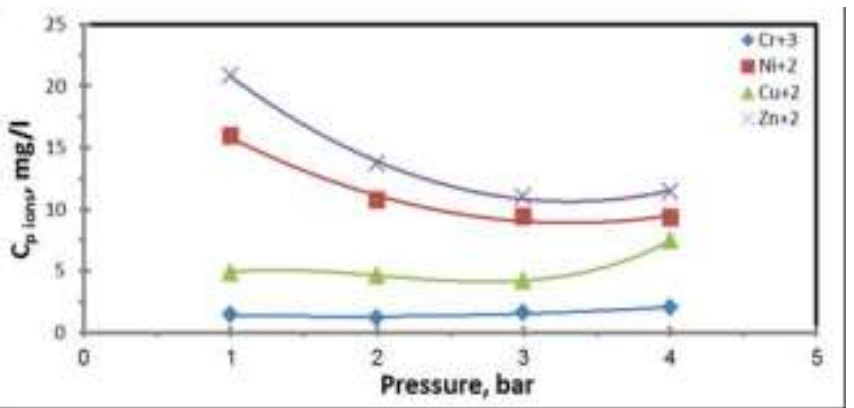

Figure 5: Effect of Pressure on Permeate Concentration $\left(Q_{F}=40 \mathrm{l} / \mathrm{h}, \mathrm{T}=26^{\circ} \mathrm{C}, \mathrm{C}_{\mathrm{F} \text { ions }}=300 \mathrm{mg} / \mathrm{l}, \mathrm{t}=30 \mathrm{~min}\right)$

\subsubsection{Effect of Feed Flow Rate}

Figs.(6) and (7) show the effect of feed flow rate on flux and the concentration of heavy metal ions in permeate. The flux of the permeate increases with increase in feed flow rate (cross flow velocity). These increment means that there is a boundary layer concentration polarization at the surface of the membrane, as the flow rate or cross flow velocity has been increased this boundary layer has been decreased. This behavior is agreement withMurthy and Chaudhari, 2009 [30]. The increase in feed flow rate from 20 to $50 \mathrm{l} / \mathrm{h}$ resulted in the increase in flux of $15.85 \%$ for zinc, $23.29 \%$ for copper, $6.25 \%$ for nickel and $7.19 \%$ for chromium.

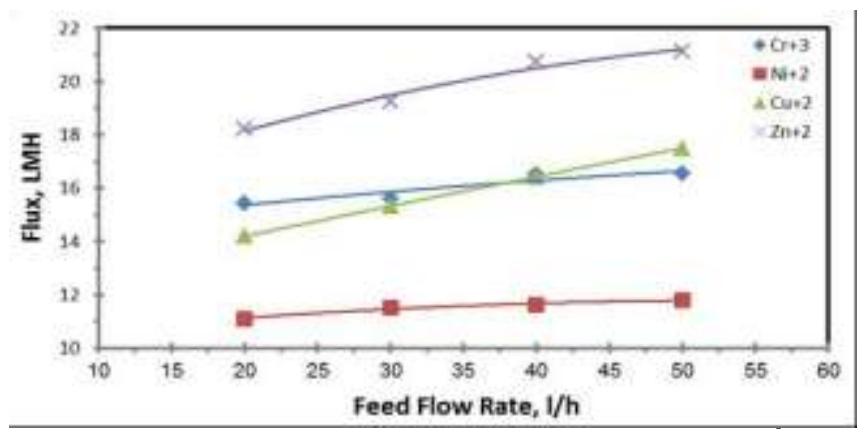

Figure 6: Effect of Flow Rate on Flux $\left(\mathrm{P}=2\right.$ bar, $\mathrm{T}=26^{\circ} \mathrm{C}, \mathrm{C}_{\mathrm{F}}$ ions $=300 \mathrm{mg} / \mathrm{l}, \mathrm{t}=30 \mathrm{~min}$ )

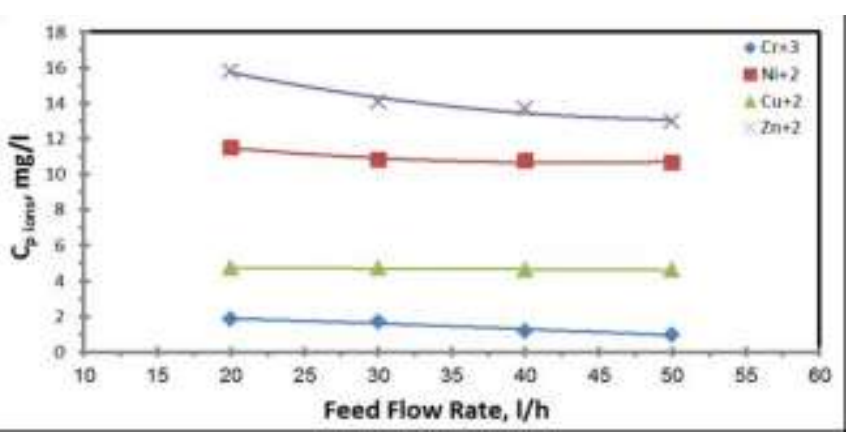

Figure 7: Effect of Flow Rate on Permeate Concentration $\left(\mathrm{P}=2\right.$ bar, $\left.\mathrm{T}=26^{\circ} \mathrm{C}, \mathrm{C}_{\mathrm{F} \text { ions }}=300 \mathrm{mg} / \mathrm{l}, \mathrm{t}=30 \mathrm{~min}\right)$

The increase in feed flow rate leads to a decrease in the permeate concentration of ions. Mass transfer coefficient increases with increase in feed flow rate which decreases the concentration polarization anddecrease the permeate concentration. The increase in feed flow rate from 20 to 50 $1 / \mathrm{h}$ resulted in the decrease of permeate concentration of $17.85 \%$ for zinc, $2.64 \%$ for copper, $7.13 \%$ for nickel and $46.95 \%$ for chromium. This behavior is agreement withGherasim and Mikulášek, 2014 [13], Ahn et al., 1999
[27], Frare`s et al., 2005 [31] and Boricha and Murthy, 2009 [32].

The polyamide nanofiltration membrane gives a high efficiency for removal of chromium, copper, zinc and nickel ions and it has allowed permeation of these ions to the lower than permissible limits.

\subsection{RO Process}

Figs.(8) to (13) show the result of RO process for the effect of feed flow rate, feed concentration, and pressure on flux and permeate concentration. The flux for nanofiltration is higher than that from reverse osmosis membranes, this due to the pore size of nanofiltration membrane which is larger than that of reverse osmosis membrane as a result the permeability of pure water for nanofiltration is approximately twice that of RO.The concentration of heavy metal ions in permeate for nanofiltration is higher than that from reverse osmosis membranes. The concentration or rejection has been affected by size exclusion than other mechanisms, the rejection for RO system mainly depends on solution diffusion transport.

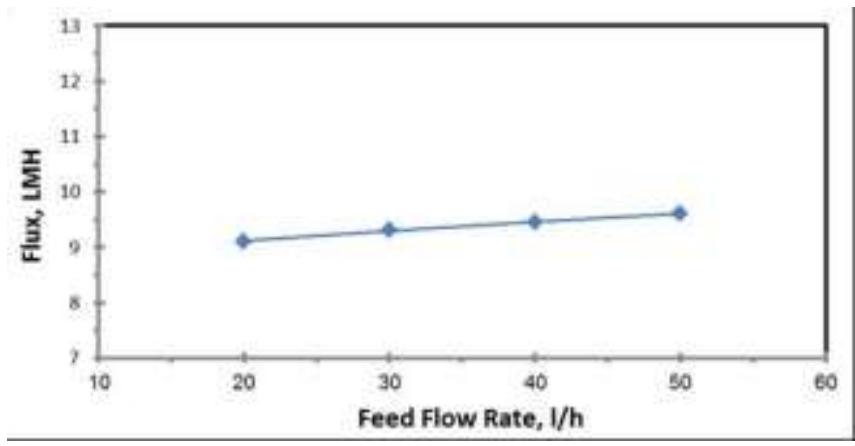

Figure 8: Effect of Flow Rate on Flux for Nickel Ions ( $\mathrm{t}=30$ $\min , \mathrm{T}=26^{\circ} \mathrm{C}, \mathrm{P}=2$ bar, $\mathrm{C}_{\mathrm{F} \mathrm{Ni}}{ }^{+2}=300 \mathrm{mg} / \mathrm{l}, \mathrm{pH}=6$ )

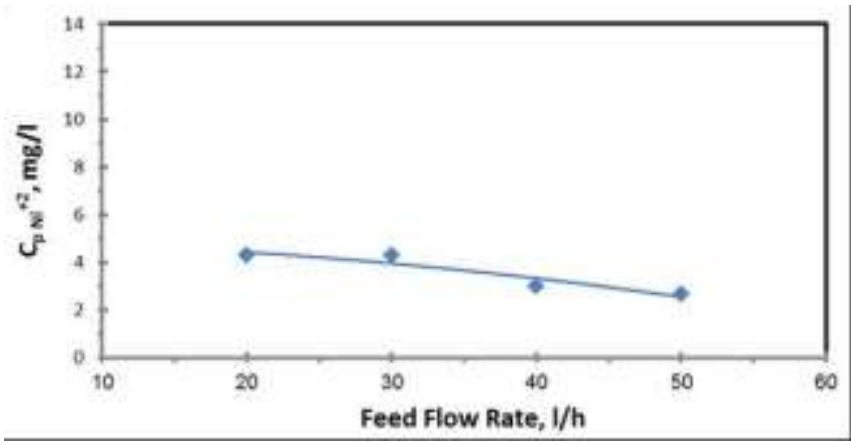

Figure 9: Effect of Flow Rate on Permeate Concentration of Nickel Ions ( $\mathrm{t}=30 \mathrm{~min}, \mathrm{~T}=26^{\circ} \mathrm{C}, \mathrm{P}=2 \mathrm{bar}, \mathrm{C}_{\mathrm{F} \mathrm{Ni}}{ }^{+2}=300 \mathrm{mg} / \mathrm{l}$, $\mathrm{pH}=6)$

\section{Volume 6 Issue 12, December 2017}


International Journal of Science and Research (IJSR)

ISSN (Online): 2319-7064

Index Copernicus Value (2016): 79.57 | Impact Factor (2015): 6.391

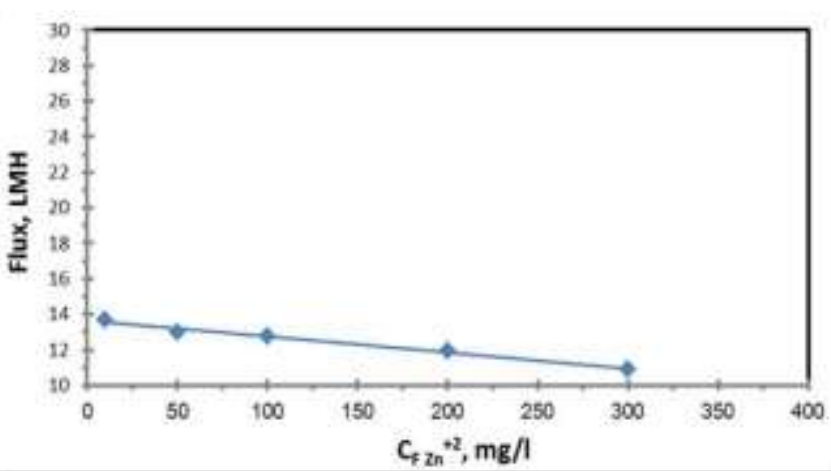

Figure 10: Effect of Feed Concentration of Zinc Ions on Flux ( $\mathrm{t}=30 \mathrm{~min}, \mathrm{~T}=26^{\circ} \mathrm{C}, \mathrm{P}=2 \mathrm{bar}, \mathrm{Q}_{\mathrm{F}}=40 \mathrm{l} / \mathrm{h}, \mathrm{pH}=6$ )

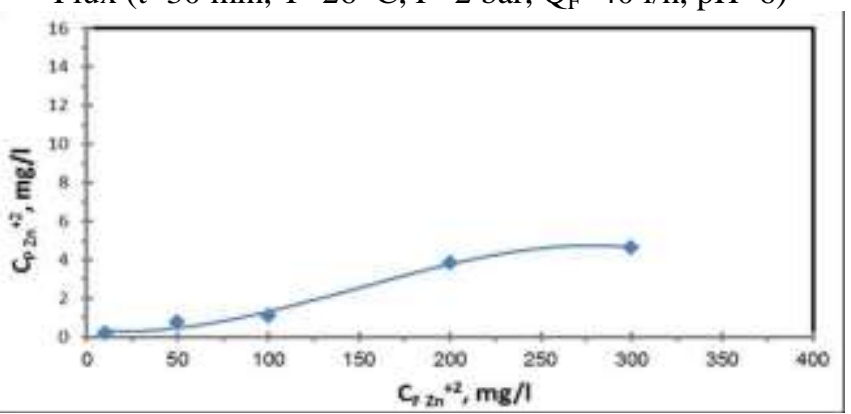

Figure 11: Effect of Feed Concentration of Zinc Ions on Permeate Concentration ( $\mathrm{t}=30 \mathrm{~min}, \mathrm{~T}=26^{\circ} \mathrm{C}, \mathrm{P}=2 \mathrm{bar}, \mathrm{Q}_{\mathrm{F}}=40$ $1 / \mathrm{h}, \mathrm{pH}=6)$

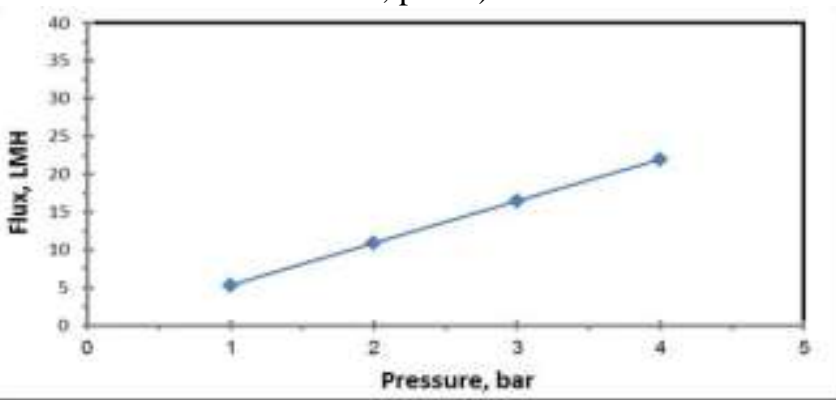

Figure 12: Effect of Pressure on Flux for Zinc Ions $(t=30$ $\min , \mathrm{T}=26{ }^{\circ} \mathrm{C}, \mathrm{Q}_{\mathrm{F}}=40 \mathrm{l} / \mathrm{h}, \mathrm{C}_{\mathrm{F} \mathrm{Zn}}{ }^{+2}=300 \mathrm{mg} / \mathrm{l}, \mathrm{pH}=6$ )

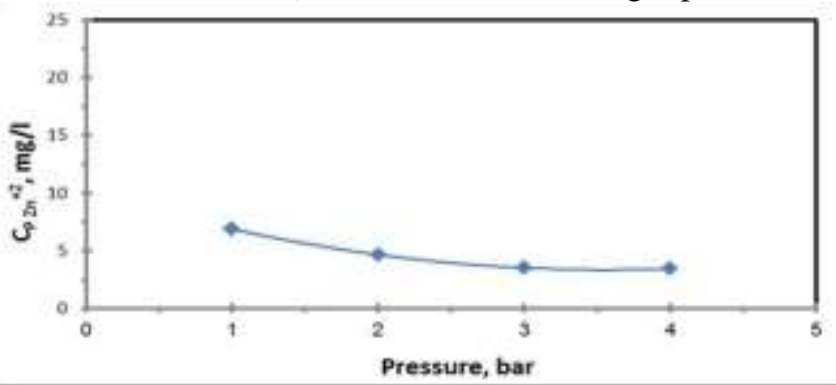

Figure 13: Effect of Pressure on Permeate Concentration of Zinc Ions $\left(\mathrm{t}=30 \mathrm{~min}, \mathrm{~T}=26^{\circ} \mathrm{C}, \mathrm{Q}_{\mathrm{F}}=40 \mathrm{l} / \mathrm{h}, \mathrm{C}_{\mathrm{F} \mathrm{Zn}}{ }^{+2}=300 \mathrm{mg} / \mathrm{l}\right.$, $\mathrm{pH}=6$ )

Some experiments has been made with constant feed concentration. This experiments has been made for each heavy metal ion in nanofiltration and reverse osmosis membranes at constant operating conditions to knowledge the rejection for each ion at constant feed concentration. This is shown in Figs.(14) and (15). The rejection for chromium in NF and RO is $99.7 \%$ and $99.93 \%$, for copper is $98.43 \%$ and $99.33 \%$, for zinc is $97.96 \%$ and $99.49 \%$, for nickel is $97.18 \%$ and $99.49 \%$ respectively.

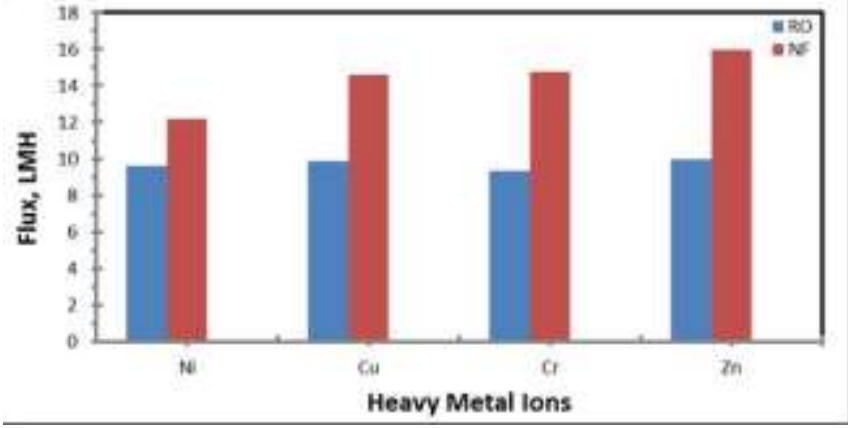

Figure 14: Comparison Between Flux of NF and RO for Constant Feed Concentration ( $\mathrm{t}=30 \mathrm{~min}, \mathrm{Q}_{\mathrm{F}}=20 \mathrm{l} / \mathrm{h}, \mathrm{T}=26^{\circ} \mathrm{C}$, $\mathrm{C}_{\mathrm{F} \text { ions }}=300 \mathrm{mg} / \mathrm{l}, \mathrm{P}=2$ bar)

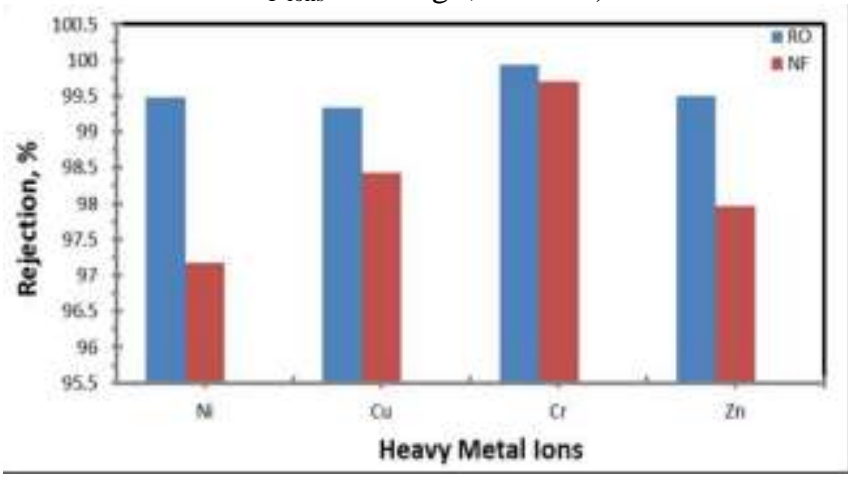

Figure 15: Comparison Between Rejection of NF and RO for Constant Feed Concentration $\left(t=30 \mathrm{~min}, \mathrm{Q}_{\mathrm{F}}=20 \mathrm{l} / \mathrm{h}, \mathrm{T}=26\right.$ ${ }^{\circ} \mathrm{C}, \mathrm{C}_{\mathrm{F} \text { ions }}=300 \mathrm{mg} / \mathrm{l}, \mathrm{P}=2 \mathrm{bar}$ )

\subsection{NF and RO for Treatment of Simulated Electroplating Wastewater}

Feed solution of heavy metals was prepared with a concentration is the same as the concentration of metals in the electroplating wastewater and the prepared concentrations based on the researcher [10]for treatment of wastewater by NF and RO membranes, flux and permeate concentration have been measured.

Figs.(16) to (21) show the effect of time for a mixture of simulated electroplating wastewater on flux, recovery percentage and the concentration of heavy metal ions in permeate for $\mathrm{NF}$ and $\mathrm{RO}$ membranes respectively. It can be seen that the behavior in the case of a mixture of heavy metals is the same when using heavy metal ions individually. The increase in time to $70 \mathrm{~min}$ resulted in the decline of flux from 16.83 to $13.48 \mathrm{LMH}$ for NF process and 10.17 to 9.32 $\mathrm{LMH}$ for RO process. The increase in time to $70 \mathrm{~min}$ resulted in the increase of recovery from 12.63 to $70.75 \%$ for NF process and 7.63 to $48.94 \%$ for RO process. The increase in time to 70 minutes resulted in the increase in permeate concentration for NF process from 0.04 to $0.57 \mathrm{mg} / \mathrm{l}$ for zinc, 1.88 to $7.01 \mathrm{mg} / \mathrm{l}$ for copper, 0.7 to $2.65 \mathrm{mg} / \mathrm{l}$ for nickel and 0.42 to $2.46 \mathrm{mg} / \mathrm{l}$ for chromium. While, for RO process the permeate concentration has been increased from 0.03 to 0.12 $\mathrm{mg} / \mathrm{l}$ for zinc, 0.85 to $2.44 \mathrm{mg} / \mathrm{l}$ for copper, 0.54 to $0.81 \mathrm{mg} / \mathrm{l}$ for nickel and 0.13 to $0.64 \mathrm{mg} / \mathrm{l}$ for chromium. 


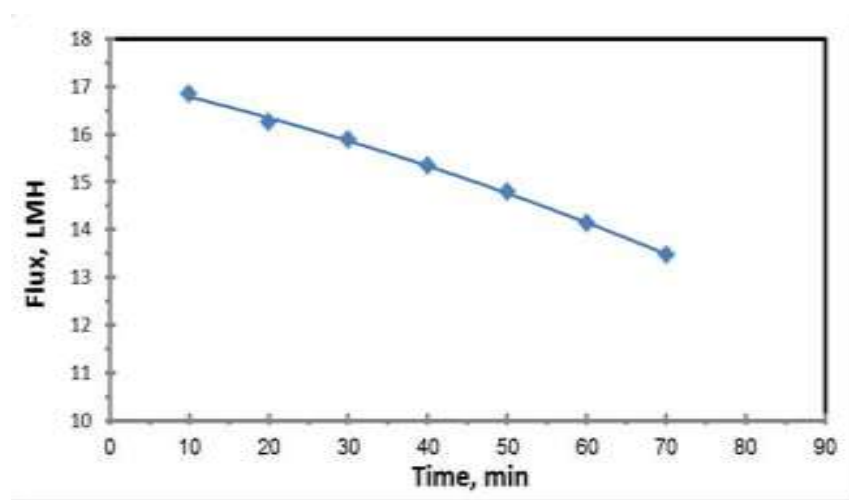

Figure 16: Effect of Time on Flux of a Synthetic

Electroplating Wastewater for NF Process $\left(Q_{F}=401 / h, T=26\right.$ ${ }^{\circ} \mathrm{C}, \mathrm{P}=2$ bar, $\mathrm{pH}=3.49, \mathrm{C}_{\mathrm{F} \mathrm{Zn}}{ }^{+2}=15 \mathrm{mg} / 1, \mathrm{C}_{\mathrm{F} \mathrm{Cu}}{ }^{+2}=60 \mathrm{mg} / 1, \mathrm{C}_{\mathrm{F}}$ $\left.\mathrm{Cr}^{+3}=125 \mathrm{mg} / \mathrm{l}, \mathrm{C}_{\mathrm{F} \mathrm{Ni}^{+2}}=150 \mathrm{mg} / \mathrm{l}\right)$

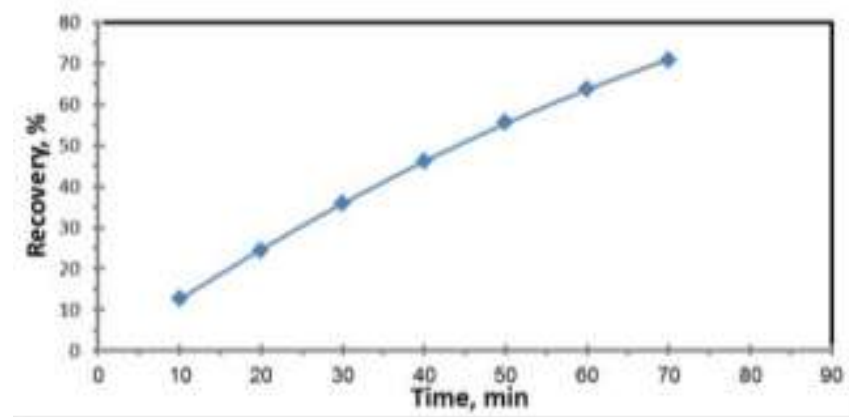

Figure 17: Effect of Time on Recovery of a Synthetic Electroplating Wastewater for NF Process $\left(Q_{F}=401 / h, T=26\right.$ ${ }^{\circ} \mathrm{C}, \mathrm{P}=2$ bar, $\mathrm{pH}=3.49, \mathrm{C}_{\mathrm{F} \mathrm{Zn}}{ }^{+2}=15 \mathrm{mg} / \mathrm{l}, \mathrm{C}_{\mathrm{F} \mathrm{Cu}}{ }^{+2}=60 \mathrm{mg} / 1, \mathrm{C}_{\mathrm{F}}$ $\left.\mathrm{Cr}^{+3}=125 \mathrm{mg} / \mathrm{l}, \mathrm{C}_{\mathrm{F} \mathrm{Ni}}{ }^{+2}=150 \mathrm{mg} / \mathrm{l}\right)$

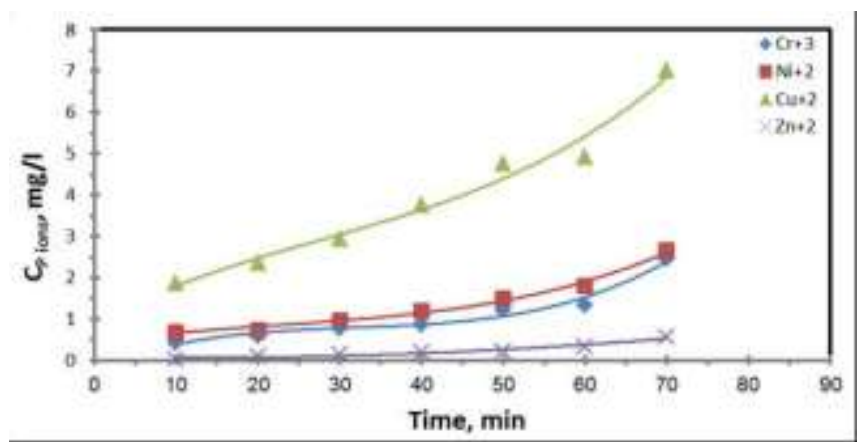

Figure 18: Effect of Time on Permeate Concentration of a Synthetic Electroplating Wastewater for NF Process $\left(Q_{F}=40\right.$ $1 / \mathrm{h}, \mathrm{T}=26^{\circ} \mathrm{C}, \mathrm{P}=2$ bar, $\mathrm{pH}=3.49, \mathrm{C}_{\mathrm{F} \mathrm{Zn}}{ }^{+2}=15 \mathrm{mg} / \mathrm{l}, \mathrm{C}_{\mathrm{F} \mathrm{Cu}}{ }^{+2}=60$ $\mathrm{mg} / \mathrm{l}, \mathrm{C}_{\mathrm{F} \mathrm{Cr}}{ }^{+3}=125 \mathrm{mg} / \mathrm{l}, \mathrm{C}_{\mathrm{F} \mathrm{Ni}}{ }^{+2}=150 \mathrm{mg} / \mathrm{l}$ )

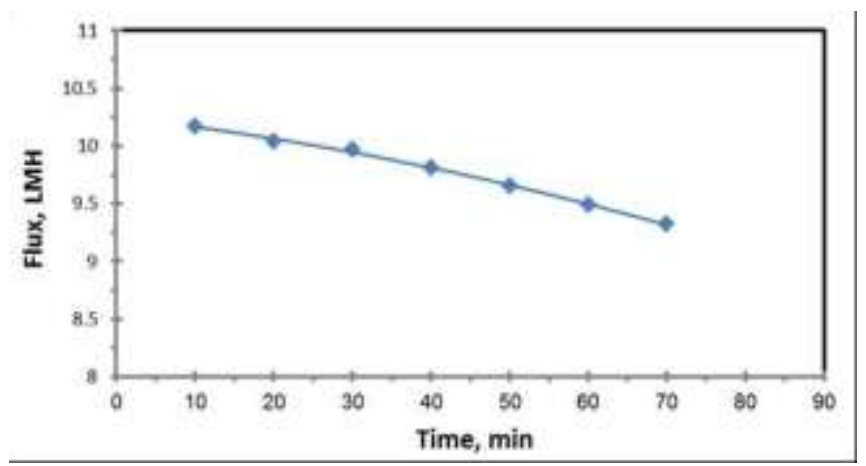

Figure 19: Effect of Time on Flux of a Synthetic

Electroplating Wastewater for RO Process $\left(Q_{F}=401 / h, T=26\right.$
${ }^{\circ} \mathrm{C}, \mathrm{P}=2$ bar, $\mathrm{pH}=3.49, \mathrm{C}_{\mathrm{F} \mathrm{Zn}}{ }^{+2}=15 \mathrm{mg} / \mathrm{l}, \mathrm{C}_{\mathrm{F} \mathrm{Cu}}{ }^{+2}=60 \mathrm{mg} / \mathrm{l}, \mathrm{C}_{\mathrm{F}}$ $\left.\mathrm{Cr}^{+3}=125 \mathrm{mg} / \mathrm{l}, \mathrm{C}_{\mathrm{F} \mathrm{Ni}}{ }^{+2}=150 \mathrm{mg} / \mathrm{l}\right)$

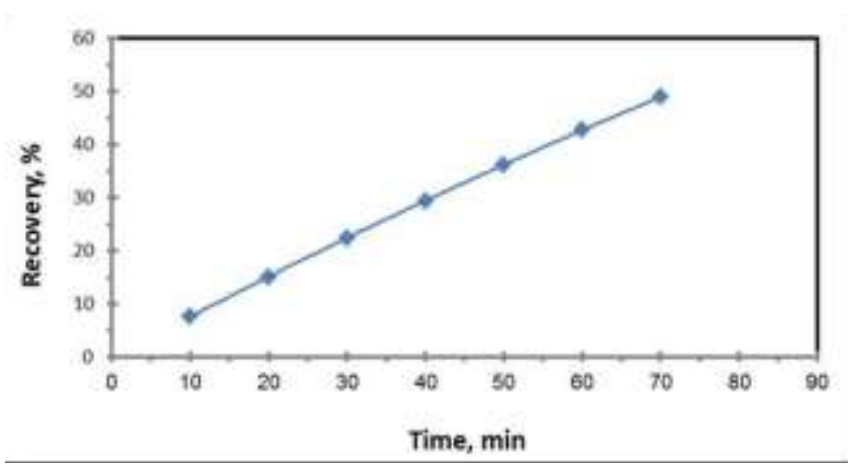

Figure 20: Effect of Time on Recovery of a Synthetic Electroplating Wastewater for RO Process $\left(Q_{F}=401 / h, T=26\right.$ ${ }^{\circ} \mathrm{C}, \mathrm{P}=2$ bar, $\mathrm{pH}=3.49, \mathrm{C}_{\mathrm{F} \mathrm{Zn}}{ }^{+2}=15 \mathrm{mg} / 1, \mathrm{C}_{\mathrm{F} \mathrm{Cu}}{ }^{+2}=60 \mathrm{mg} / \mathrm{l}, \mathrm{C}_{\mathrm{F}}$ $\left.\mathrm{Cr}^{+3}=125 \mathrm{mg} / \mathrm{l}, \mathrm{C}_{\mathrm{F} \mathrm{Ni}}{ }^{+2}=150 \mathrm{mg} / \mathrm{l}\right)$

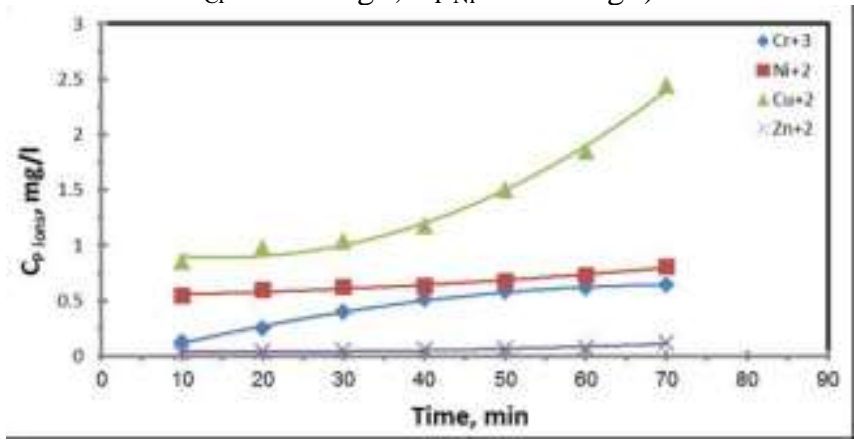

Figure 21: Effect of Time on Permeate Concentration of a Synthetic Electroplating Wastewater for RO Process $\left(Q_{F}=40\right.$ $1 / \mathrm{h}, \mathrm{T}=26^{\circ} \mathrm{C}, \mathrm{P}=2$ bar, $\mathrm{pH}=3.49, \mathrm{C}_{\mathrm{F} \mathrm{Zn}}{ }^{+2}=15 \mathrm{mg} / \mathrm{l}, \mathrm{C}_{\mathrm{F} \mathrm{Cu}}{ }^{+2}=60$ $\left.\mathrm{mg} / \mathrm{l}, \mathrm{C}_{\mathrm{F} \mathrm{Cr}}{ }^{+3}=125 \mathrm{mg} / \mathrm{l}, \mathrm{C}_{\mathrm{F} \mathrm{Ni}}{ }^{+2}=150 \mathrm{mg} / \mathrm{l}\right)$

For a mixture of simulated electroplating wastewater, nanofiltration and reverse osmosis membranes have a high removal efficiency for heavy metal ions. In other words, the concentration of heavy metal ions in permeate was less than allowable limits.

\subsection{Mathematical Modeling}

In this research, the water flux calculated theoretically and it's compare with the experimental results for zinc chloride salt $\left(\mathrm{ZnCl}_{2}\right)$.

As shown in Figs.(22) and (23), the data shows a linear relationship between pure water flux and driving force $(\Delta \mathrm{P})$. Polyamide membrane permeability for pure water is determined from the slope of this curve, the value of $k_{w}$ was obtained $13.02 \mathrm{l} / \mathrm{m}^{2}$.bar.h for NF membrane and 6.74 $1 / \mathrm{m}^{2}$.bar.h for RO membrane. Figs.(24) and (25) show a linear relationship between mass flux of solute and driving force $(\Delta \mathrm{C})$. Membrane permeability for salt is determined from the slope of this curve, the value of $k_{s}$ was obtained $1.28 * 10^{-3} \mathrm{~m} / \mathrm{h}$ for NF membrane and $2.5^{*} 10^{-4} \mathrm{~m} / \mathrm{h}$ for RO membrane.

In this study, the difference between theoretical and experimental results were small and better than other researcher because the impact of the concentration

\section{Volume 6 Issue 12, December 2017}




\section{International Journal of Science and Research (IJSR) \\ ISSN (Online): 2319-7064 \\ Index Copernicus Value (2016): 79.57 | Impact Factor (2015): 6.391}

polarization and some other factors were appeared in the model equations. The accuracy between theoretical and experimental results ranging from $86-99.4 \%$ for NF and 9399.9\% for RO membranes.

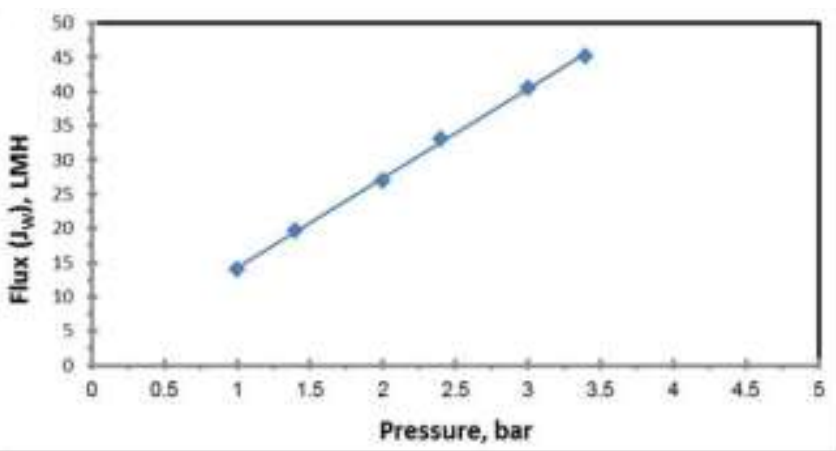

Figure 22: Pressure vs. Pure Water Flux for NF Process $\left(Q_{F}=30 \mathrm{l} / \mathrm{h}, \mathrm{T}=26^{\circ} \mathrm{C}, \mathrm{t}=10 \mathrm{~min}\right)$

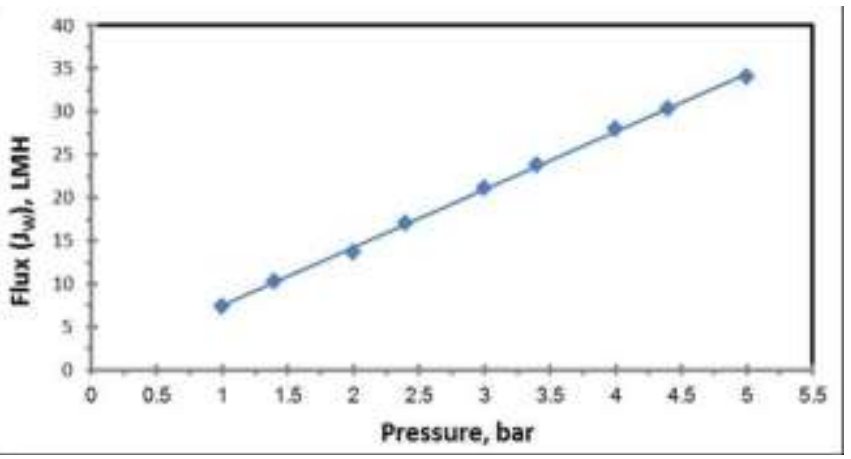

Figure 23: Pressure vs. Pure Water Flux for RO Process $\left(Q_{F}=30 \mathrm{l} / \mathrm{h}, \mathrm{T}=26^{\circ} \mathrm{C}, \mathrm{t}=10 \mathrm{~min}\right)$

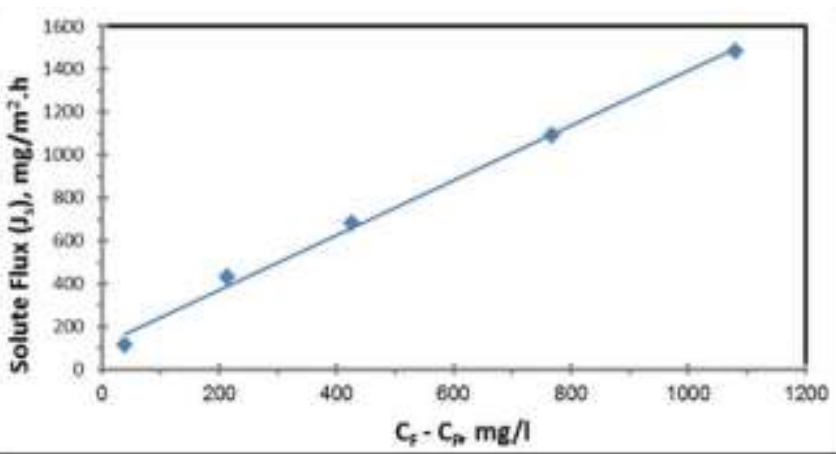

Figure 24: Concentration Difference vs. Solute Flux for NF Process $\left(\mathrm{Q}_{\mathrm{F}}=40 \mathrm{l} / \mathrm{h}, \mathrm{T}=26^{\circ} \mathrm{C}, \mathrm{t}=30 \mathrm{~min}, \mathrm{P}=2\right.$ bar $)$

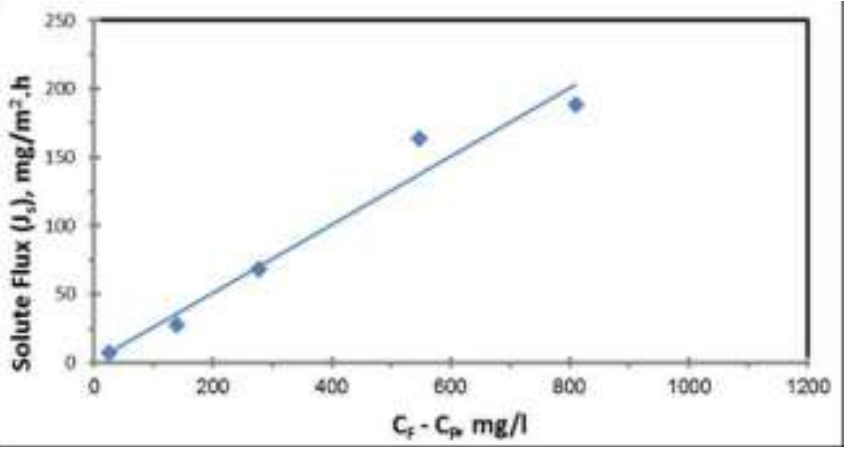

Figure 25: Concentration Difference vs. Solute Flux for RO Process $\left(\mathrm{Q}_{\mathrm{F}}=40 \mathrm{l} / \mathrm{h}, \mathrm{T}=26^{\circ} \mathrm{C}, \mathrm{t}=30 \mathrm{~min}, \mathrm{P}=2\right.$ bar $)$
Fig.(26) shows the effect of feed concentration of zinc ions on theoretical and experimental flux for zinc. Fig.(27) shows the effect of operating pressure on theoretical and experimental flux for zinc.

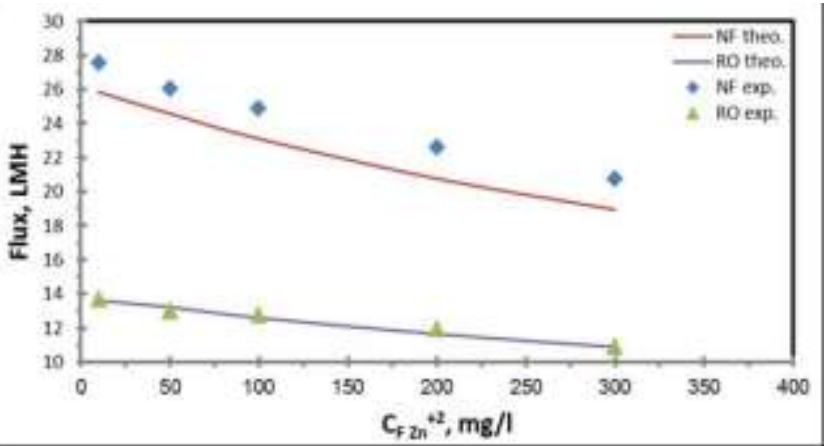

Figure 26: Flux vs. Feed Concentration of Zinc Ions $\left(Q_{F}=40\right.$ $1 / \mathrm{h}, \mathrm{T}=26^{\circ} \mathrm{C}, \mathrm{P}=2$ bar, $\mathrm{t}=30 \mathrm{~min}, \mathrm{pH}=6$ )

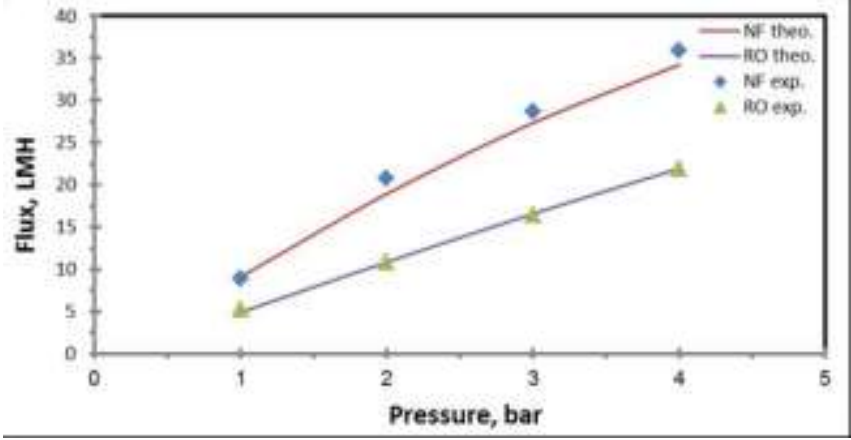

Figure 27: Flux vs. Pressure $\left(Q_{F}=40 \mathrm{l} / \mathrm{h}, \mathrm{T}=26^{\circ} \mathrm{C}, \mathrm{t}=30 \mathrm{~min}\right.$, $\mathrm{C}_{\mathrm{F} \mathrm{Zn}}{ }^{+2}=300 \mathrm{mg} / \mathrm{l}, \mathrm{pH}=6$ )

\section{Conclusions}

1) The polyamide nanofiltration and reverse osmosis membranes are a suitable methods for the removal of heavy metals from wastewater due to giving a pure water and allowed permeation of chromium, copper, zinc and nickel ions to the lower than permissible limits individually andin the case of the synthetic electroplating wastewater.

2) The water flux for NF and RO membranes decreases with raising in feed concentration,increases by raising the applied pressure and flow rate.

3) The maximum recovery percentage of water was $80.88 \%$ for $\mathrm{NF}$ and $54.56 \%$ for RO.

4) The rejection for chromium in NF and RO is $99.7 \%$ and $99.9 \%$, for copper is $98.4 \%$ and $99.3 \%$, for zinc is $97.9 \%$ and $99.5 \%$, for nickel is $97.2 \%$ and $99.5 \%$ respectively.

5) The flux for nanofiltration is higher than that from reverse osmosis membranes, The concentration of heavy metal ions in permeate for nanofiltration is higher than that from reverse osmosis membranes.

6) The permeability of pure water for nanofiltration membrane (AXEON NF4-1812) is approximately twice that of RO membrane (VONTRON-ULP 1812-50).

7) Mathematical model with the existence of the effect of concentration polarization gives a good agreement between theoretical and experimental results. The accuracy between theoretical and experimental results

Volume 6 Issue 12, December 2017 www.ijsr.net 


\section{International Journal of Science and Research (IJSR) \\ ISSN (Online): 2319-7064}

Index Copernicus Value (2016): 79.57 | Impact Factor (2015): 6.391

ranging from $86-99.4 \%$ for $\mathrm{NF}$ and $93-99.9 \%$ for $\mathrm{RO}$ membranes.

\section{References}

[1] Alzahrani, S., Mohammad, A. W., Hilal, N., Abdullah, P., and Jaafar, O., 2013. "Comparative Study of NF and RO Membranes in the Treatment of Produced WaterPart I: Assessing Water Quality". Desalination. 315, 18-26.

[2] Srivastava, N. K. and Majumder, C. B., 2008. "Novel Biofiltration Methods for the Treatment of Heavy Metals from Industrial Wastewater". Journal of Hazardous Materials. 151, 1-8.

[3] Zhu, W. P., Gao, J., Sun, S. P., Zhang, S. and Chung, T. S., 2015. "Poly (Amidoamine) Dendrimer (PAMAM) Grafted on Thin Film Composite (TFC) Nanofiltration (NF) Hollow Fiber Membranes for Heavy Metal Removal". Journal of Membrane Science. 487, 117126.

[4] Barakat, M. A., 2011. "New Trends in Removing Heavy Metals from Industrial Wastewater". Arabian Journal of Chemistry. 4, 361-377.

[5] Kurniawan, T. A., Chan, G. Y. S., Lo, W. H. and Babel, S., 2006. "Physico-Chemical Treatment Techniques for Wastewater Laden with Heavy Metals". Chemical Engineering Journal. 118, 83-98.

[6] Mohammed, S. A., 2014. "Removal of Multi Toxic Metal Ions Electrochemically Under Dynamic Conditions". Ph.D. thesis, Baghdad University.

[7] Wahaab, R. A., Moawad, A. K., AbouTaleb, E., Ibrahim, H. S. and El-Nazer, H. A. H., 2010. "Combined Photocatalytic Oxidation and Chemical Coagulation for Cyanide and Heavy Metals Removal from Electroplating Wastewater". World Applied Sciences Journal. 8, 462-469.

[8] Abhang, R. M., Wani , K. S., Patil, V. S., Pangarkar, B. L. and Parjane, S. B., 2013. "Nanofiltration for Recovery of Heavy Metal Ions from Waste Water - A Review". International Journal of Research in Environmental Science and Technology. 3, 29-34.

[9] Al-Alawy, A. F. and Salih, M. H., 2017. " Comparative Study between Nanofiltration and Reverse Osmosis Membranes for the Removal of Heavy Metals from Electroplating Wastewater". Journal of Engineering. 23, 4, 1-21.

[10] Wei, X., Kong, X., Wang, S., Xiang, H., Wang, J. and Chen, J., 2013. "Removal of Heavy Metals from Electroplating Wastewater by Thin-Film Composite Nanofiltration Hollow-Fiber Membranes". Industrial \& Engineering Chemistry Research. 52, 17583-17590.

[11] Addai, M. K., 2014. "Removal and Recovery of Heavy Metals by Nickel Smelter Slag". M.Sc. thesis, Western Ontario University.

[12] AbdAlameer, A. M., 2011. "Dye Removal from Industrial Wastewater Using Membrane Technology". M.Sc. thesis, University of Technology.

[13] Gherasim, C. V. and Mikulášek, P., 2014. "Influence of Operating Variables on the Removal of Heavy Metal Ions from Aqueous Solutions by Nanofiltration". Desalination. 343, 67-74.

[14] Keong, L. K., 2007. "Feed Spacer of Spiral Wound Membrane Module for Nanofiltration and Reverse
Osmosis: Modeling, Simulation and Design". Ph.D. Thesis.

[15] Hamdzah, M. B., 2007. "Low Pressure Reverse Osmosis Membrane for Rejection of Heavy Metals". M.Sc. thesis, University Teknologi Malaysia.

[16] Ba, C., 2010. "Design of Advanced Reverse Osmosis and Nanofiltration Membranes for Water Purification". Ph.D. Thesis, University of Illinois.

[17] Crittenden, J. C., Trussell, R. R., Hand, D. W., Howe K. J. and Tchobanoglous, G., 2012. "MWH's Water Treatment Principles and Design". Third edition, John Wiley and Sons, Inc.

[18] Kucera, J., 2010. "Reverse Osmosis Design, Processes, and Applications for Engineers". John Wiley \& Sons, Inc. Hoboken, New Jersey, and Scrivener Publishing LLC, Salem, Massachusetts.

[19] A1-Bastaki, N. M. and Abbas, A., 1999. "Modeling an Industrial Reverse Osmosis Unit". Desalination. 126, 33-39.

[20] Al-Alawy, A. F. and Salih, M. H., 2016. "Experimental Study and Mathematical Modelling of Zinc Removal by Reverse Osmosis Membranes". Iraqi Journal of Chemical and Petroleum Engineering. 17, 3, 57-73.

[21] Khudair, W. N., 2011. "Reduction of Concentrating Poisonous Metallic Radicals from Industrial Wastewater by Forward and Reverse Osmosis". M.Sc. thesis, Baghdad University.

[22] Williams, M. E., 2003. "A Review of Reverse Osmosis Theory". Corporation and Williams Engineering Services Company, Inc.

[23] Schock, G. and Miguel, A., 1987. "Mass Transfer and Pressure Loss in Spiral Wound Modules". Desalination. 64, 339-352.

[24] Jamal, K., Khan, M. and Kamil, M., 2004. "Mathematical Modelling of Reverse Osmosis". Desalination. 160, 29-42.

[25] Absar, B., Kadi, S. E. L. and Belhamiti, O., 2008. "Mathematical Modeling of Reverse Osmosis Process by the Orthogonal Collocation on Finite Element Method". Asian Journal of Applied Sciences. 1, 1-18.

[26] Al-Rashdi, B. A. M., Johnson, D. J. and Hilal, N., 2013. "Removal of Heavy Metal Ions by Nanofiltration". Desalination. 315, 2-17.

[27] Ahn, K. H., Song, K. G., Cha, H. Y. and Yeom, I. T., 1999. "Removal of Ions in Nickel Electroplating Rinse Water Using Low-Pressure Nanofiltration". Desalination. 122, 77-84.

[28] Lee, J. W., Kwon, T. O. and Moon, I. S., 2006. "Performance of Polyamide Reverse Osmosis Membranes for Steel Wastewater Reuse". Desalination. 189, 309-322.

[29] Chai, X., Chen, G., Yue, P. L. and Mi, Y., 1997. "Pilot Scale Membrane Separation of Electroplating Waste Water by Reverse Osmosis". Journal of Membrane Science. 123, 235-242.

[30] Murthy, Z. V. P. and Chaudhari, L. B., 2009. "Separation of Binary Heavy Metals from Aqueous Solutions by Nanofiltration and Characterization of the Membrane Using Spiegler-Kedem Model". Chemical Engineering Journal. 150, 181-187.

[31] Frare`s, N. B., Taha, S. and Dorange, G., 2005. "Influence of the Operating Conditions on the

\section{Volume 6 Issue 12, December 2017}




\section{International Journal of Science and Research (IJSR)}

ISSN (Online): 2319-7064

Index Copernicus Value (2016): 79.57 | Impact Factor (2015): 6.391

Elimination of Zinc Ions by Nanofiltration". Desalination. 185, 245-253.

[32] Boricha, A. G. and Murthy, Z. V. P., 2009.

"Preparation, Characterization and Performance of Nanofiltration Membranes for the Treatment of Electroplating Industry Effluent". Separation and Purification Technology. 65, 282-289.

Volume 6 Issue 12, December 2017 www.ijsr.net 